\title{
Characterization by Tandem Mass Spectrometry of Stable Cysteine Sulfenic Acid in a Cysteine Switch Peptide of Matrix Metalloproteinases
}

\author{
Vivekananda Shetty, Daniel S. Spellman, and Thomas A. Neubert \\ Skirball Institute of Biomolecular Medicine and Department of Pharmacology, New York University School \\ of Medicine, New York, New York, USA
}

\begin{abstract}
Cysteine sulfenic acid (Cys-SOH) is an elusive intermediate in reactive oxygen species-induced oxidation reactions of many proteins such as peroxiredoxins and tyrosine phosphatases. Cys- $\mathrm{SOH}$ is proposed to play a vital role in catalytic and signaling functions. The formation of cysteine sulfinic acid $\left(\mathrm{Cys}-\mathrm{SO}_{2} \mathrm{H}\right)$ and cysteine sulfonic acid $\left(\mathrm{Cys}-\mathrm{SO}_{3} \mathrm{H}\right)$ has been implicated in the activation of matrix metalloproteinase-7 (MMP-7) and oxidation of thiol to cysteine sulfinic acid has been associated with the autolytic cleavage of MMP-7. We have examined the formation of cysteine sulfenic acid in a synthetic peptide PRCGVPDVA, which is a cysteine switch domain of MMP-7 and other matrix metalloproteases. We have prepared the cysteine sulfenic acid containing peptide, PRC(SOH)GVPDVA, by reaction with hydroxyl radicals generated by the Fenton reaction $\left(\mathrm{Fe}^{+2} / \mathrm{H}_{2} \mathrm{O}_{2}\right)$. We characterized this modified peptide by tandem mass spectrometry and accurate mass measurement experiments. In addition, we used 7-chloro-4-nitrobenzo-2-oxa-1,3-diazol (NBD-Cl) reagent to form an adduct with PRC (SOH)GVPDVA to provide additional evidence for the viability of PRC(SOH)GVPDVA in solution. We also characterized an intramolecular cysteine sulfinamide cross-link product PRC $[S(O) N] G V P D V A$ based on tandem mass spectrometry and accurate mass measurement experiments. These results contribute to the understanding of a proteolytic cleavage mechanism that is traditionally associated with MMP activation. (J Am Soc Mass Spectrom 2007, 18, 1544-1551) @ 2007 American Society for Mass Spectrometry
\end{abstract}

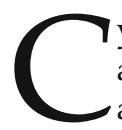
ysteine sulfenic acid (Cys-SOH) formation plays a vital role in regulating the catalysis, function and redox signaling of several proteins such as peroxiredoxins, phosphatases, transcription factors, and members of the $\mathrm{NAD}(\mathrm{P}) \mathrm{H} /$ disulfide reductase family [1-5]. Cysteine sulfenic acids in proteins are also widespread posttranslational modifications that can result from oxidative stress conditions [6]. Cysteine residues that possess a low $\mathrm{pKa}$ in proteins can be selectively oxidized by reactive oxygen species $\left(\mathrm{H}_{2} \mathrm{O}_{2}\right.$, alkyl hydroperoxides, peroxy nitrite, hypochlorous acid) to cysteine sulfenic acid via a cysteine thiolate anion $\left(\mathrm{Cys}_{-} \mathrm{S}^{-}\right)$intermediate [7-10]. Since cysteine sulfenic acid is a highly reactive intermediate, it further reacts with any accessible thiol to form a disulfide or rapidly undergoes further oxidation with oxidants such as $\mathrm{H}_{2} \mathrm{O}_{2}$ to give cysteine sulfinic acid $\left(\mathrm{Cys}-\mathrm{SO}_{2} \mathrm{H}\right)$ and cysteine sulfonic acid $\left(\mathrm{Cys}-\mathrm{SO}_{3} \mathrm{H}\right)$ [2].

Cysteine sulfenic acid has been identified by $\mathrm{X}$-ray crystallography and 13C-NMR techniques in the active site of the NADH peroxidase protein from Enterococcus

Address reprint requests to Dr. Thomas A. Neubert, Skirball Institute Lab 5-18, 540 First Avenue, New York, New York 10016, USA. E-mail: neubert@ saturn.med.nyu.edu faecalis [11, 12]. However, cysteine sulfenic acid was not observed in solution in the case of PTP1-B [3] although it was characterized in the crystal form of this protein [13]. Because of the high reactivity of cysteine sulfenic acid due to unfavorable solvent interactions and local environment of most proteins [2], its definitive identification became possible only after trapping with chemical reagents such as dimedone [14], a fluorophorecontaining analog of dimedone [15], NBD-Cl [16], and recent labeling experiments with biotin-maleimide after arsenite specific reduction [6] followed by mass spectrometry. Fuangthong and Helmann [17] observed a mass increase consistent with cysteine sulfenic acid in intact OhrR repressor protein by ESI-MS using NBD-Cl trapping experiments. However, to the best of our knowledge, there is no report in the literature describing the characterization of underivatized cysteine sulfenic acid at the peptide level by tandem mass spectrometry experiments, which are very important for ruling out possible oxidative modifications of other amino acids such as methionine and phenylalanine.

Macrophage-derived matrix metalloproteinases (MMPs) are a family of zinc and calcium dependent enzymes implicated in regulating matrix degradation in inflammation, arthritis, cancer, cardiovascular and neu- 
rodegenerative diseases [18-23]. A highly conserved domain called the cysteine switch (amino acid sequence PRCXXPD) is proposed to regulate the activity of all MMPs except for MMP-23 [19, 22, 23]. Likewise, MMP-7 also contains another cysteine switch sequence, PRCGVPDVA, in its pro-domain. Fu et al. demonstrated that pro-MMP-7 can be activated by $\mathrm{HOCl}$ oxidation, but not $\mathrm{H}_{2} \mathrm{O}_{2}$ oxidation, converting cysteine to cysteine sulfinic acid and cysteine sulfonic acid [24]. Thus oxygenation of thiol residue in the cysteine switch peptide PRCGVPDVA was found to be a key event in the autolytic cleavage of pro-MMP-7. However, these authors did not investigate the formation of a cysteine sulfenic acid intermediate that could be involved in the activation mechanism of MMP-7. This prompted us to investigate cysteine sulfenic acid formation in the cysteine switch sequence PRCGVPDVA of MMPs.

In this study, we have used Fenton reagents $\left(\mathrm{Fe}^{+2} /\right.$ $\mathrm{H}_{2} \mathrm{O}_{2}$ ) to produce highly reactive hydroxyl radicals $(\mathrm{OH})$ that can react with the sulfhydryl group in cysteine to give a variety of oxidation products. The formation of hydroxyl radicals in the Fenton reaction has been shown to be potentially more damaging to cells than other reactive oxidants [25]. In fact, recently we have prepared cysteine sulfinic acid and cysteine sulfonic acid in PRCGVPDVA by hydroxyl radicals generated in the Fenton reaction and studied their fragmentation mechanism by ion trap tandem mass spectrometry [26]. Here we report the preparation and characterization by HPLC, tandem mass spectrometry and accurate mass measurement of a stable cysteine sulfenic acid in a synthetic peptide, PRC(SOH)GVPDVA that mimics the cysteine switch sequence of MMPs.

\section{Experimental}

The peptide PRCGVPDVA was a gift by Professor Yinsheng Wang, University of California at Riverside, Riverside, CA. NBD-Cl was purchased from Aldrich. PRCGVPDVA was oxidized using Fenton reagents $\left(\mathrm{Fe}^{+2} / \mathrm{H}_{2} \mathrm{O}_{2}\right)$ as reported previously [26]. ${ }^{\circ}$ Briefly, ${ }^{\circ} 1{ }^{\circ} \mathrm{mM}$ peptide solution was incubated at $37^{\circ} \mathrm{C}$ in the presence of $0.5 \mathrm{mM} \mathrm{FeSO}_{4}$ and $0.2 \mathrm{mM} \mathrm{H}_{2} \mathrm{O}_{2}$ for $\sim 30 \mathrm{~min}$. The reaction was terminated by adding aliquots of methionine solution until its concentration reached $1 \mathrm{mM}$. Based on the number of counts in the extracted ion chromatograms $^{\circ}\left(\right.$ Figure $\left.^{\circ} 1\right),{ }^{\circ}$ cysteine $^{\circ}$ sulfonic $^{\circ}$ acid $^{\circ}$ was found to be the major product followed by cysteine sulfinic acid, cysteine sulfenic acid and cysteine sulfinamide (-C[S\{O\}N]-) products. Adducts of PRCGVPDVA and cysteine sulfenic acid with NBD-Cl were synthesized ${ }^{\circ}$ according ${ }^{\circ}$ to $^{\circ}$ Ellis ${ }^{\circ}$ et $^{\circ}$ al..$^{\circ}[16]^{\circ}$ except $^{\circ}$ that ${ }^{\circ}{ }^{\circ} e^{\circ}$ carried out the reaction under aerobic conditions. We did not rigorously optimize the reaction conditions to increase the yield of cysteine sulfenic acid and cysteine sulfinamide products or the adducts of PRC(SNBD)GVPDVA and PRC[S(O)-NBD]GVPDVA.

Data-dependent nano-LC-MS/MS experiments were

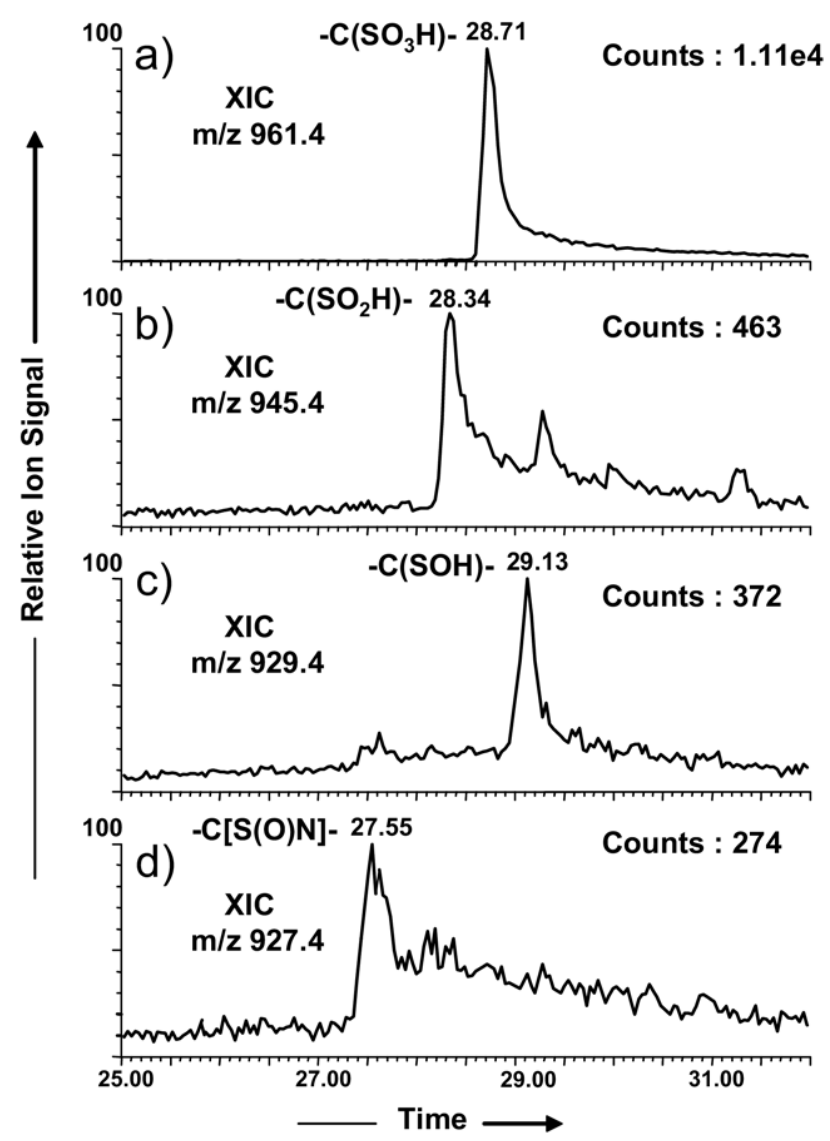

Figure 1. Extracted ion chromatograms of major cysteine oxidation products of the cysteine switch domain peptide PRCGVPDVA from MMP-7.

carried out using a Waters CapLC (Milford, MA) coupled directly to a Waters Q-TOF Micromass spectrometer (Milford, MA) through a Picotip needle (New Objective, Woburn, MA) and a home-made pre-column flow splitter. The analytical column was a $75 \mu \mathrm{m}$ I.D. $\times$ $15 \mathrm{~cm}$ PepMap C18 (LC Packings, Sunnyvale, CA). Mobile phase A was $2 \%$ acetonitrile $/ 0.1 \%$ formic acid, and mobile phase B was $90 \%$ acetonitrile $/ 0.1 \%$ formic acid in water. The gradient was $5 \%$ to $90 \%$ B over 45 min with a flow rate of $400 \mathrm{~nL} / \mathrm{min}$. Automatic switching between MS and MS/MS modes was controlled by MassLynx 4.0 (Micromass) software, dependent on both signal intensity and charge states from MS to MS/MS and on either signal intensity or time from MS/MS to MS. In the case of direct infusion MS/MS experiments, $50 \%$ acetonitrile in $0.1 \%$ formic acid was used as the carrier and electrospray solvent at a flow rate of 500 $\mathrm{nL} / \mathrm{min}$. A $1 \mu \mathrm{L}$ aliquot of $2 \mu \mathrm{M}$ peptide solution was injected via a divert-valve in each run under following source conditions: spray voltage 1500 to $1800 \mathrm{~V}$, cone voltage $40 \mathrm{~V}$, source temperature $80^{\circ} \mathrm{C}$. Argon was used as a collision gas for all MS/MS experiments. The quadrupole mass filter before the TOF analyzer was set with LM and HM resolution of 14.0 (arbitrary units), which is equivalent to a 1.0-Da mass window for transmission of precursor ions. Each spectrum was 
obtained by averaging $\sim 25$ scans, and the scan time was $1 \mathrm{~s} / \mathrm{scan}$. The Q-TOF Micro instrument was calibrated with [Glu1]-fibrinopeptide B and the data in both MS and MS/MS modes were acquired at 5000 resolution. In the case of accurate mass measurement experiments, the precursor ion was used as a lock mass to calibrate the masses of the fragment ions. To assess stability of the oxidized peptide forms, $5 \mu \mathrm{L}$ of a single sample stored at $4{ }^{\circ} \mathrm{C}$ was injected every two hours after quenching the Fenton reaction onto a Symmetry $5 \mu \mathrm{m}$ particle, $180 \mu \mathrm{m} \times 20 \mathrm{~mm} \mathrm{C18}$ pre-column (Waters, Milford, MA), then washed 5 min with $1 \%$ acetonitrile in $0.1 \%$ formic acid at a flow rate of $20 \mu \mathrm{L} / \mathrm{min}$. After washing, peptides were eluted and passed through an Atlantis $3 \mu \mathrm{m}$ particle, $75 \mu \mathrm{m} \times 100 \mathrm{~mm}$ C18 analytical column (Waters) with a gradient of $1 \%$ to $80 \%$ acetonitrile in $0.1 \%$ formic acid. The gradient was delivered over $60 \mathrm{~min}$ by a nano-ACQUITY UPLC (Waters) at a flow rate of $250 \mathrm{~nL} / \mathrm{min}$ to a fused silica distal end- coated tip nano-electrospray needle (New Objective, Woburn, MA). MS survey scans were collected on a Q-TOF Premiere (Waters/Micromass, Milford, MA). Extracted ion chromatograms were generated for the $m / z$ of interest $(927.4,929.4,945.4,961.4)$ and an equal number of scans were summed across the signal peak for each corresponding time point. Normalized intensities were calculated by dividing reaction products ion counts by those of an internal standard ([Glu1]-fibrinopeptide $\mathrm{B},+2 \mathrm{~m} / \mathrm{z} 785.8)$. Values for two replicate experiments were averaged and standard deviations calculated.

\section{Results and Discussion}

Our goal was to separate and identify by nano-LCMS/MS all the cysteine oxidation products formed in the hydroxyl radical reaction. The oxidation reaction mixture including the PRCGVPDVA peptide was ana-

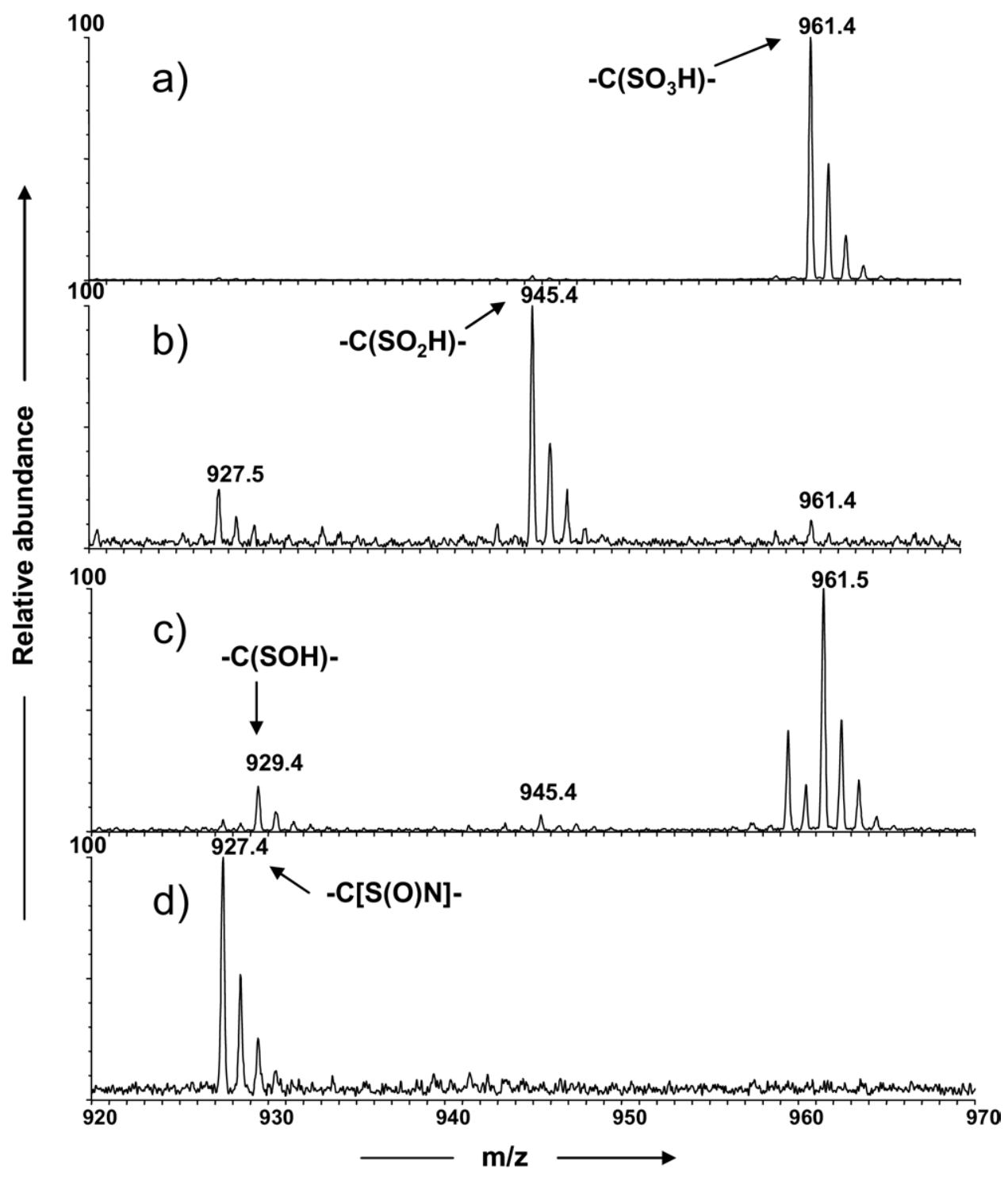

Figure 2. Partial mass spectra of major cysteine oxidation products of the PRCGVPDVA peptide. 


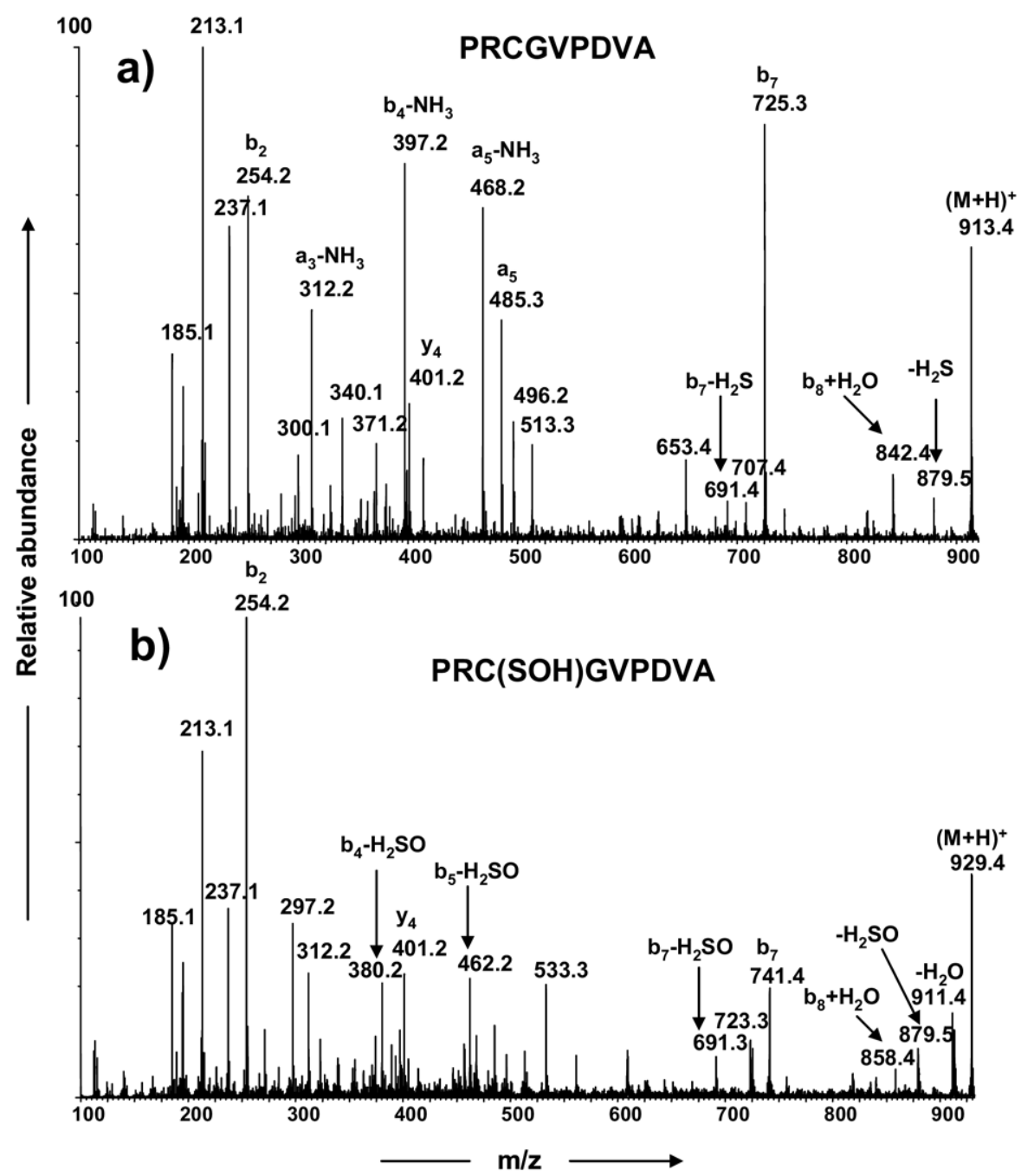

Figure 3. $\mathrm{MS} / \mathrm{MS}^{\circ}$ spectra $^{\circ}$ of $^{\circ}$ the ${ }^{\circ}$ precursor $^{\circ}$ peptides $^{\circ}$ shown $^{\circ}$ in $^{\circ}$ Figure $^{\circ} 2:^{\circ}(\mathbf{a})^{\circ}$ unmodified $^{\circ}$ cysteine switch peptide PRCGVPDVA $(\mathrm{m} / \mathrm{z}$ 913.4) and (b) cysteine sulfenic acid product PRC(SOH)GVPDVA $(m / z$ 929.4).

lyzed in a data-dependent nano-LC-MS/MS experiment with the emphasis on the identification of the cysteine $^{\circ}$ sulfenic $^{\circ}$ acid $^{\circ}$ product. $^{\circ}$ Figure $^{\circ} 1^{\circ}$ shows $^{\circ}$ the extracted ion chromatograms (XIC) of possible products that resulted from the Fenton oxidation reaction and their masses are shown in their respective mass spectra (Figure ${ }^{\circ}$ 2) ${ }^{\circ}{ }^{\circ}$ The ${ }^{\circ}$ products $^{\circ}$ at ${ }^{\circ} \mathrm{m} / \mathrm{z}$ 927.4, $, 929.4,{ }^{\circ} 945.4,{ }^{\circ}$ and $961.4^{\circ}$ in $^{\circ}$ Figure $^{\circ} 2^{\circ}$ differed $^{\circ}$ by $^{\circ} 14,{ }^{\circ} 16,{ }^{\circ} 32,{ }^{\circ}$ and $^{\circ} 48^{\circ} \mathrm{Da}$, respectively, from the unmodified precursor peptide PRCGVPDVA $(\mathrm{m} / \mathrm{z}$ 913.5). The latter two products, $\mathrm{m} / \mathrm{z}$ $945.5(+36 \mathrm{Da})$ and $\mathrm{m} / z$ $961.4(+48 \mathrm{Da})$ were characterized as cysteine sulfinic acid and cysteine sulfonic acid, respectively, ${ }^{\circ}$ as $^{\circ}$ reported $^{\circ}$ previously $^{\circ}$ by $^{\circ}$ us $^{\circ}[26] .{ }^{\circ}$ However, we could not obtain sequence information for the products of $\mathrm{m} / \mathrm{z} 929.5(+1) / \mathrm{m} / \mathrm{z} 465.2(+2)$ or $\mathrm{m} / \mathrm{z} 927.5$ $(+1) / \mathrm{m} / z 464.2(+2)$ in our on-line LC-MS/MS experiments. Therefore, we carried out direct infusion MS/MS experiments for the singly charged ions of all modified peptides including the ion of $\mathrm{m} / \mathrm{z}$ 929.5, for which a precursor selection window of only 1 Da was used to avoid fragmenting impurities from adjacent peaks.

\section{Characterization of Cysteine Sulfenic Acid [PRC(SOH)GVPDVA]}

The MS/MS spectra of unmodified PRCGVPDVA $(\mathrm{m} / \mathrm{z}$ 913.5) and the modified product at $m / z 929.5$ are shown in $^{\circ}$ Figure $^{\circ} 3 .^{\circ} \mathrm{In}^{\circ}{ }^{\circ}$ Figure $^{\circ} 3 b,{ }^{\circ}$ the ${ }^{\circ}$ formation ${ }^{\circ}$ of ${ }^{\circ}$ the ${ }^{\circ} y_{4}(\mathrm{~m} / z$ 401) and $b_{2}(m / z 254)$ ions rules out the possibility of modification of either of the two prolines or the arginine in PRCGVPDVA. However, the formation of the ion at $\mathrm{m} / \mathrm{z} 741\left(\mathrm{~b}_{7}+16 \mathrm{Da}\right)$ indicates that cysteine is most likely modified. In addition to this, the formation of the diagnostic ion at $m / z 879\left(-\mathrm{H}_{2} \mathrm{SO}\right)$ and the loss of neutral $\mathrm{H}_{2} \mathrm{SO}$ from $b_{3}, b_{4}$, and $b_{7}$ ions confirm that the cysteine is modified with an oxygen atom to cysteine sulfenic acid, PRC(SOH)GVPDVA. This $m / z 879$ ion and an ion at $m / z$ 691, both due to loss of $\mathrm{H}_{2} \mathrm{~S}$ from the 
Table 1. High resolution data for the $(\mathrm{M}+\mathrm{H})^{+}$ions of PRCGVPDVA, PRC[S(O)N]GVPDVA and PRC(SOH)GVPDVA

\begin{tabular}{|c|c|c|c|c|}
\hline Parent ion $(\mathrm{M}+\mathrm{H})^{+}$ & Meas'd mass & Calc mass & $\triangle \mathrm{PPM}$ & Formula \\
\hline PRCGVPDVA & 913.4565 & 913.4566 & -0.1 & $\mathrm{C}_{38} \mathrm{H}_{65} \mathrm{~N}_{12} \mathrm{O}_{12} \mathrm{~S}$ \\
\hline $\operatorname{PRC}[\mathrm{S}(\mathrm{O}) \mathrm{N}] \mathrm{GVPDVA}$ & 927.4390 & 927.4358 & 3.5 & $\mathrm{C}_{38} \mathrm{H}_{63} \mathrm{~N}_{12} \mathrm{O}_{13} \mathrm{~S}$ \\
\hline PRC(SOH)GVPDVA & 929.4442 & 929.4515 & -7.8 & $\mathrm{C}_{38} \mathrm{H}_{65} \mathrm{~N}_{12} \mathrm{O}_{13} \mathrm{~S}$ \\
\hline
\end{tabular}

unmodified peptide, are also formed in the MS/MS spectrum $^{\circ}$ of ${ }^{\circ}$ PRCGVPDVA $^{\circ}\left(\right.$ Figure $\left.^{\circ} 3 a\right) .{ }^{\circ}$ Furthermore, we observed that the MS/MS spectra of higher oxidation products, cysteine sulfinic acid and cysteine sulfonic acid also exhibit similar neutral losses from precursor ions as well as fragment ions (data not shown). In fact, the facile loss of neutral $\mathrm{H}_{2} \mathrm{SO}_{3}$ from both parent and fragment ions is well documented in the literature $\left[26,{ }^{\circ} 27-29\right] . .^{\circ}$ The $^{\circ}$ structural ${ }^{\circ}$ assignments $^{\circ}$ for ${ }^{\circ}(\mathrm{M}+\mathrm{H})^{+}$ ions at $\mathrm{m} / \mathrm{z} 929.4,927.4$ and 913.4 in the MS spectrum (Table 1$)^{\circ}$ and ${ }^{\circ}$ for ${ }^{\circ}$ some $^{\circ}$ of ${ }^{\circ}$ the ${ }^{\circ}$ key ${ }^{\circ}$ fragment ${ }^{\circ}$ ions ${ }^{\circ}$ formed in their MS/MS spectra are further supported by the results ${ }^{\circ}$ of $^{\circ}$ high-resolution ${ }^{\circ} \mathrm{MS} / \mathrm{MS}^{\circ}$ experiments ${ }^{\circ}$ (Tables $2^{\circ}$ and 3 ). Weqave observed that ${ }^{\circ}$ the formation ${ }^{\circ}$ of strong $\mathrm{b}_{3}$ and $\mathrm{y}_{6}$ ions due to preferential cleavage c-terminal to the oxidized cysteine occurs only in the cysteine sulfinic acid but not other oxidized forms. This is due to the formation of stable cyclic CID fragmentation products from the cysteine sulfinic acid form in an energetically favorable cleavage pathway similar to those formed C-terminal ${ }^{\circ}$ to $^{\circ}$ aspartic $^{\circ}$ acid $^{\circ}$ residues $^{\circ}\left(\right.$ Figure $^{\circ} 3^{\circ}$ and reference $\left.{ }^{\circ}[26]\right) .{ }^{\circ} \operatorname{In}^{\circ}$ cases $^{\circ}$ where ${ }^{\circ}$ observed $^{\circ} \mathrm{m} / \mathrm{z}$ values differ by more than $5 \mathrm{ppm}$ from predicted values, this was due to low intensity ion signals for the CID fragment ions derived from the low abundance oxidation products.

In addition to the above experimental evidence demonstrating that a stable cysteine sulfenic acid [PRC(SOH)GVPDVA] was produced in solution, we further supported this finding by forming the adduct of $^{\circ}$ cysteine $^{\circ}$ sulfenic $^{\circ}$ acid $^{\circ}$ with $^{\circ} \mathrm{NBD}^{-\mathrm{Cl}^{\circ}}[16] .{ }^{\circ}$ The MS/MS spectra of NBD adducts of PRCGVPDVA and PRC(SOH)GVPDVA ${ }^{\circ}$ are $^{\circ}$ shown $^{\circ}$ in $^{\circ}$ Figure $^{\circ} 4 .{ }^{\circ}$ The $^{\circ}$ spec- $^{-}$ trum ${ }^{\circ}{ }^{\circ}{ }^{\circ}$ igure $4 b^{\circ}{ }^{\circ}$ clearly $^{\circ}$ showed ${ }^{\circ}{ }^{\circ}$ mass ${ }^{\circ}$ shift $^{\circ}$ for $^{\circ}$ the $^{\circ} b_{7}$ $(\mathrm{m} / \mathrm{z}$ 904) ion due to the cysteine sulfenic acid adduct with NBD. In addition, a diagnostic ion at $\mathrm{m} / \mathrm{z} 879$ $[-\mathrm{NBD}-\mathrm{S}(\mathrm{O}) \mathrm{H}]$ indicated the formation of a PRC[S(O)NBD]GVPDVA adduct and confirmed the viability

Table 2. High resolution data for fragment ions in the MS/MS spectrum of $(\mathrm{M}+\mathrm{H})^{+}$ions of PRCGVPDVA

\begin{tabular}{lccrll}
\hline \multicolumn{1}{c}{ Ion } & $\begin{array}{c}\text { Meas'd } \\
\text { mass }\end{array}$ & $\begin{array}{c}\text { Calc } \\
\text { mass }\end{array}$ & \multicolumn{1}{c}{$\Delta$ PPM } & \multicolumn{1}{c}{ Formula } \\
\hline \hline$(\mathrm{M}+\mathrm{H})^{+}$ & 913.4565 & 913.4565 & 0.0 & $\mathrm{C}_{38} \mathrm{H}_{65} \mathrm{~N}_{12} \mathrm{O}_{12} \mathrm{~S}$ \\
$-\mathrm{H}_{2} \mathrm{~S}$ & 879.4518 & 879.4688 & -19.4 & $\mathrm{C}_{38} \mathrm{H}_{63} \mathrm{~N}_{12} \mathrm{O}_{12}$ \\
$\mathrm{~b}_{7}$ & 725.3406 & 725.3405 & 0.2 & $\mathrm{C}_{30} \mathrm{H}_{49} \mathrm{~N}_{10} \mathrm{O}_{9} \mathrm{~S}$ \\
$\mathrm{~b}_{5}-\mathrm{NH}_{3}$ & 496.2332 & 496.2342 & -2.0 & $\mathrm{C}_{21} \mathrm{H}_{34} \mathrm{~N}_{7} \mathrm{O}_{5} \mathrm{~S}$ \\
$\mathrm{a}_{5}$ & 485.2651 & 485.2658 & -1.5 & $\mathrm{C}_{20} \mathrm{H}_{37} \mathrm{~N}_{8} \mathrm{O}_{4} \mathrm{~S}$ \\
$\mathrm{a}_{5}-\mathrm{NH}_{3}$ & 468.2420 & 468.2393 & 5.8 & $\mathrm{C}_{20} \mathrm{H}_{34} \mathrm{~N}_{7} \mathrm{O}_{4} \mathrm{~S}$ \\
$\mathrm{~b}_{3}-\mathrm{NH}_{3}$ & 340.1415 & 340.1443 & -8.3 & $\mathrm{C}_{14} \mathrm{H}_{22} \mathrm{~N}_{5} \mathrm{O}_{3} \mathrm{~S}$ \\
$\mathrm{a}_{3}-\mathrm{NH}_{3}$ & 312.1568 & 312.1494 & 23.6 & $\mathrm{C}_{13} \mathrm{H}_{22} \mathrm{~N}_{5} \mathrm{O}_{2} \mathrm{~S}$ \\
\hline
\end{tabular}

of PRC(SOH)GVPDVA in solution. Thus both PRC (SOH)GVPDVA and PRC[S(O)-NBD]GVPDVA underwent very similar fragmentation pathways under these experimental conditions.

The formation of stable cysteine sulfenic acid in $\mathrm{PRC}(\mathrm{SOH}) \mathrm{GVPDVA}$ is also in agreement with the reported reactivity order of all 20 amino acids towards hydroxyl radicals generated in radiolysis experiments $[30]^{\circ}$ where ${ }^{\circ}$ cysteine ${ }^{\circ}$ was $^{\circ}$ shown $^{\circ}$ to ${ }^{\circ}$ be $^{\circ}$ the ${ }^{\circ}$ most $^{\circ}$ highly reactive amino acid residue. According to rules for the stabilization $^{\circ}$ of $^{\circ}$ cysteine $^{\circ}$ sulfenic $^{\circ}$ acid $^{\circ}$ in $^{\circ}$ solution $^{\circ}[2]$, hydrogen bonding is one of the main factors that can influence the stability of cysteine sulfenic acid in proteins in addition to the absence of proximal Cys-SH and limited nonpolar solvent access. We propose a hydrogen bonding effect in the formation of stable cysteine sulfenic acid in PRC(SOH)GVPDVA due to the formation of a strong intramolecular hydrogen bond between the cysteine-SOH group and the guanidine group of arginine (Scheme 1).

We performed a time course experiment to demonstrate the stability of the cysteine sulfenic acid peptide after quenching the Fenton reaction. Within experimental error, we found no detectable loss of the sulfenic acid form ${ }^{\circ}$ after $^{\circ} 25^{\circ} h^{\circ}$ (Figure $^{\circ} 5$ ).

\section{Characterization of Cysteine Sulfinamide Cross-Link (PRC[S\{O\}N]GVPDVA)}

To characterize the structure of the modified product at ${ }^{\circ} \mathrm{m} / \mathrm{z}$ 927.5 (Figure $^{\circ} 1 \mathrm{~d}$ ), ${ }^{\circ}$ its $^{\circ} \mathrm{MS} / \mathrm{MS}^{\circ}$ spectrum ${ }^{\circ}$ was acquired ${ }^{\circ}$ as $^{\circ}$ shown $^{\circ}$ in $^{\circ}$ Figure $^{\circ} 6 .^{\circ}$ The $^{\circ}$ formation ${ }^{\circ}$ of ${ }^{\circ}$ the ion at $\mathrm{m} / \mathrm{z} 401.5\left(\mathrm{y}_{4}\right)$ eliminates the possibility of modification at the C-terminal $\mathrm{P}, \mathrm{D}, \mathrm{V}, \mathrm{A}$ residues. The formation of ions at $m / z 739.4\left(b_{7}+14 \mathrm{Da}\right)$ and $m / z 482.2\left(a_{5}-\mathrm{NH}_{3}+14 \mathrm{Da}\right)$ suggested that the modification could be on the $\mathrm{C}, \mathrm{G}$, or $\mathrm{V}$ residues. However, the presence of low abundance diagnostic ions at $m / z 879.5(-\mathrm{SO})$ and $\mathrm{m} / z 865.5\left(-\mathrm{CH}_{2} \mathrm{SO}\right)$,

Table 3. High resolution data for fragment ions in the MS/MS spectrum of $(\mathrm{M}+\mathrm{H})^{+}$ions of PRC(SOH)GVPDVA

\begin{tabular}{lccrl}
\hline \multicolumn{1}{c}{ Ion } & $\begin{array}{c}\text { Meas'd } \\
\text { mass }\end{array}$ & $\begin{array}{c}\text { Calc } \\
\text { mass }\end{array}$ & \multicolumn{1}{c}{$\Delta$ PPM } & \multicolumn{1}{c}{ Formula } \\
\hline \hline$(\mathrm{M}+\mathrm{H})^{+}$ & 929.4515 & 929.4515 & 0.0 & $\mathrm{C}_{38} \mathrm{H}_{65} \mathrm{~N}_{12} \mathrm{O}_{13} \mathrm{~S}$ \\
$-\mathrm{H}_{2} \mathrm{O}$ & 911.4355 & 911.4409 & -5.9 & $\mathrm{C}_{38} \mathrm{H}_{63} \mathrm{~N}_{12} \mathrm{O}_{12} \mathrm{~S}$ \\
$-\mathrm{H}_{2} \mathrm{SO}$ & 879.4837 & 879.4688 & 16.9 & $\mathrm{C}_{38} \mathrm{H}_{63} \mathrm{~N}_{12} \mathrm{O}_{12}$ \\
$\mathrm{~b}_{7}$ & 741.3430 & 741.3354 & 10.3 & $\mathrm{C}_{30} \mathrm{H}_{49} \mathrm{~N}_{10} \mathrm{O}_{10} \mathrm{~S}$ \\
$\mathrm{~b}_{7}-\mathrm{H}_{2} \mathrm{SO}$ & 691.3450 & 691.3527 & -11.2 & $\mathrm{C}_{30} \mathrm{H}_{47} \mathrm{~N}_{10} \mathrm{O}_{9}$ \\
$\mathrm{y}_{4}$ & 401.2066 & 401.2036 & 7.4 & $\mathrm{C}_{17} \mathrm{H}_{29} \mathrm{~N}_{4} \mathrm{O}_{7}$ \\
$\mathrm{~b}_{4}-\mathrm{H}_{2} \mathrm{SO}$ & 380.2084 & 380.2046 & 9.9 & $\mathrm{C}_{16} \mathrm{H}_{26} \mathrm{~N}_{7} \mathrm{O}_{4}$ \\
\hline
\end{tabular}


Table 4. High resolution data for fragment ions in the MS/MS spectrum of $(\mathrm{M}+\mathrm{H})^{+}$ions of PRC[S(O)N]GVPDVA

\begin{tabular}{lccrlll}
\hline \multicolumn{1}{c}{ Ion } & $\begin{array}{c}\text { Meas'd } \\
\text { mass }\end{array}$ & $\begin{array}{c}\text { Calc } \\
\text { mass }\end{array}$ & \multicolumn{1}{c}{$\Delta$ PPM } & \multicolumn{2}{c}{ Formula } \\
\hline \hline$(\mathrm{M}+\mathrm{H})^{+}$ & 927.4358 & 927.4358 & 0.0 & $\mathrm{C}_{38} \mathrm{H}_{63} \mathrm{~N}_{12} \mathrm{O}_{13} \mathrm{~S}$ \\
$-\mathrm{SO}$ & 879.4617 & 879.4688 & -8.1 & $\mathrm{C}_{38} \mathrm{H}_{63} \mathrm{~N}_{12} \mathrm{O}_{12}$ \\
$-\mathrm{CH}_{2} \mathrm{SO}$ & 865.4400 & 865.4532 & -15.2 & $\mathrm{C}_{37} \mathrm{H}_{61} \mathrm{~N}_{12} \mathrm{O}_{12}$ \\
$\mathrm{~b}_{7}$ & 739.3200 & 739.3197 & 0.4 & $\mathrm{C}_{30} \mathrm{H}_{47} \mathrm{~N}_{10} \mathrm{O}_{10} \mathrm{~S}$ \\
$\mathrm{a}_{5}-\mathrm{NH}_{3}$ & 482.2100 & 482.2186 & -17.8 & $\mathrm{C}_{20} \mathrm{H}_{32} \mathrm{~N}_{7} \mathrm{O}_{5} \mathrm{~S}$ \\
$\mathrm{y}_{4}$ & 401.2066 & 401.2036 & -9.0 & $\mathrm{C}_{17} \mathrm{H}_{29} \mathrm{~N}_{4} \mathrm{O}_{7}$ \\
$\mathrm{~b}_{3}-\mathrm{SO}$ & 323.1865 & 323.1832 & 10.3 & $\mathrm{C}_{14} \mathrm{H}_{23} \mathrm{~N}_{6} \mathrm{O}_{3}$ \\
\hline
\end{tabular}

suggested that cysteine is modified by gain of one oxygen and loss of two hydrogens. Thus, in addition to the cysteine, $\mathrm{R}$ or $\mathrm{G}$ may also be involved in the modification to account for the $14 \mathrm{Da}$ increment from the unmodified PRCGVPDVA peptide. These observations strongly suggest that the cysteine residue of PRCGVPDVA is oxidized to form an intramolecular cysteine sulfinamide cross-link (PRC[S $\{\mathrm{O}\} \mathrm{N}] \mathrm{GVPDVA})$



Scheme 1

and that the cross-link involves the guanidine group of the arginine residue as reported previously in $\mathrm{PFRCG}^{\circ}$ and ${ }^{\circ} \mathrm{PFKCG}^{\circ}$ peptides ${ }^{\circ}[31] .^{\circ}$ The $^{\circ}$ high-resolution data obtained for some of these informative fragment ${ }^{\circ}$ ions $^{\circ}\left(\text { Table }^{\circ} 4\right)^{\circ}$ further ${ }^{\circ}$ supported ${ }^{\circ}$ the ${ }^{\circ}$ formation of a cysteine sulfinamide cross-link product. The ion at $m / z 254$ may be formed by a rearrangement

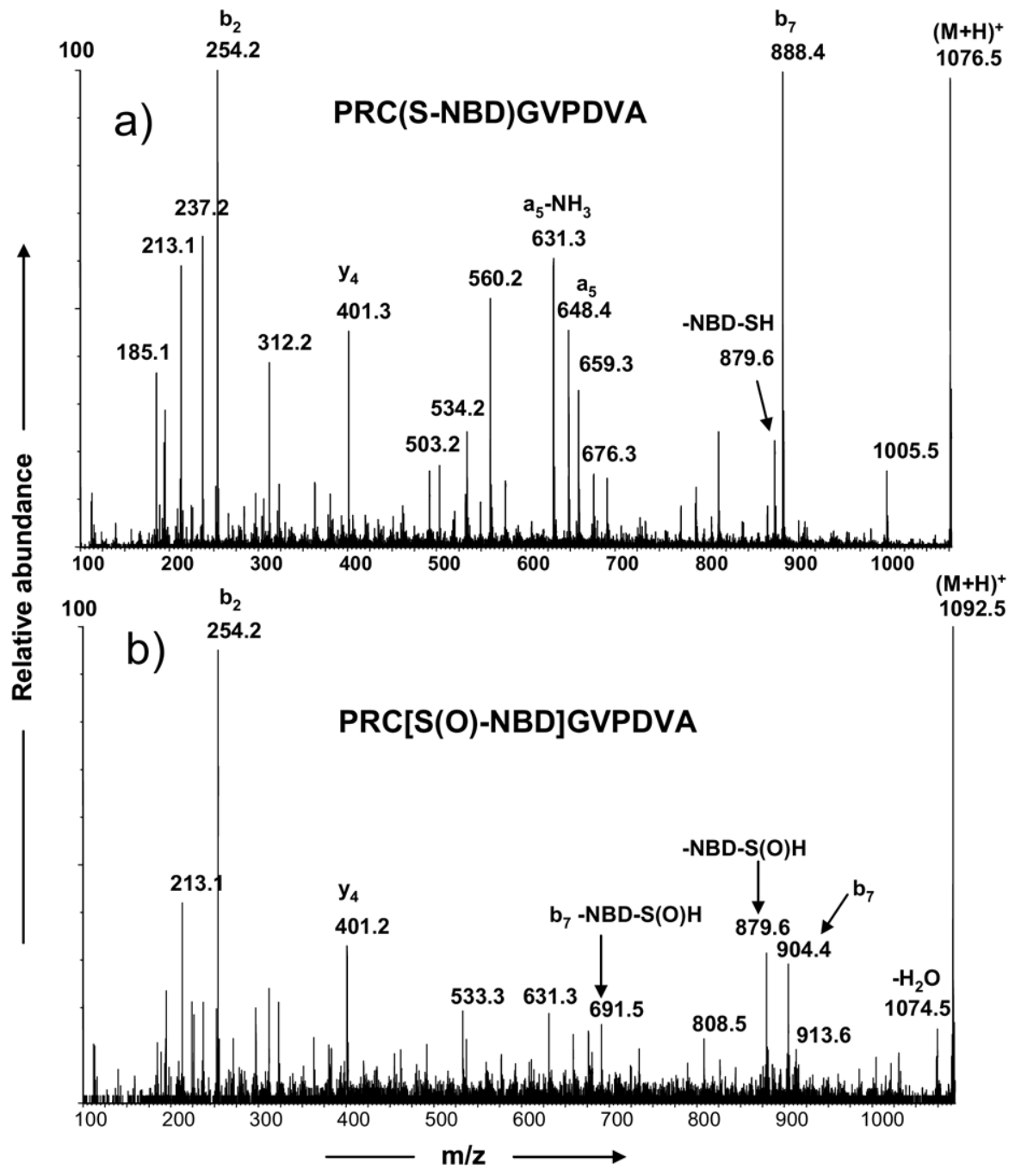

Figure 4. MS/MS spectra of (a) PRC(S-NBD)GVPDVA $(\mathrm{m} / \mathrm{z}$ 1076.5) and (b) PRC[S(O)-NBD]VPDVA $(\mathrm{m} / \mathrm{z}$ 1092.5). 


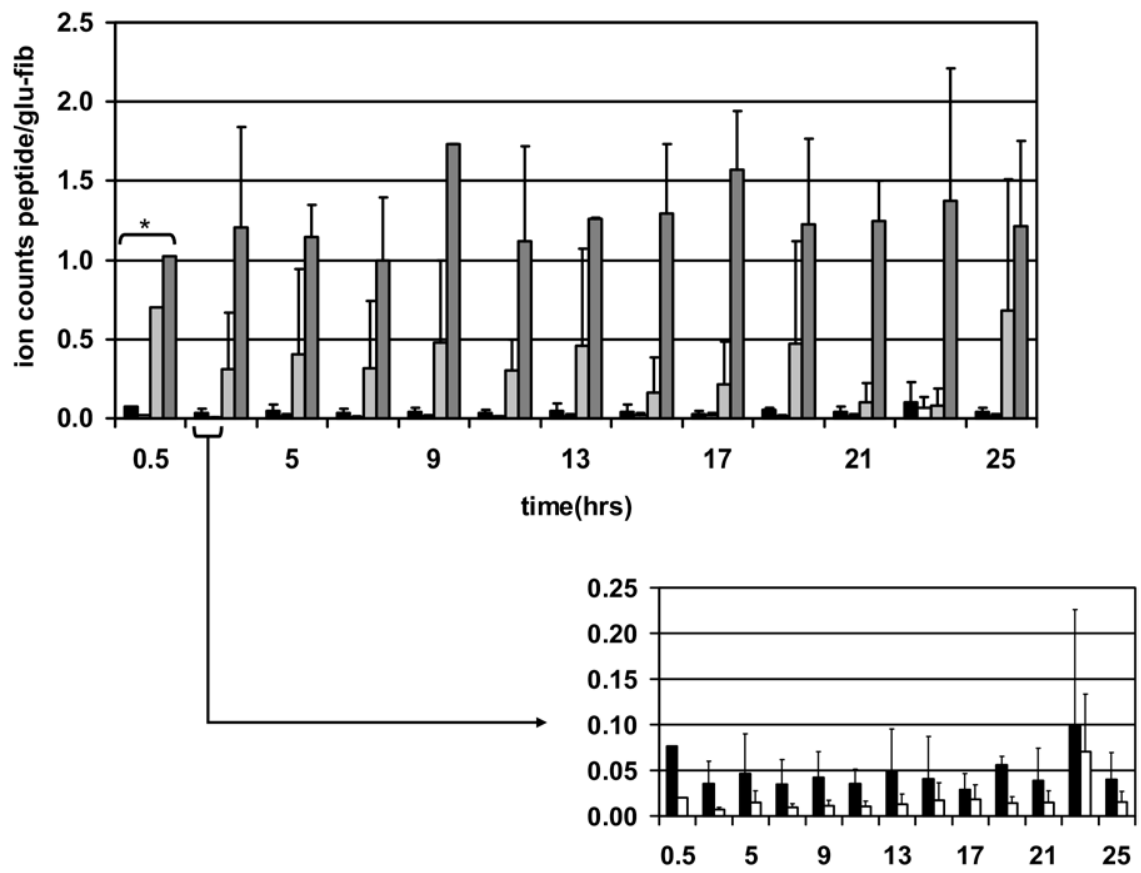

Figure 5. The stability of reaction products at $m / z 927.4(\square), 929.4(\square), 945.4(\square)$, and $961.4(\square)$ was monitored over a period of $25 \mathrm{~h}$. Samples were analyzed via LC-MS approximately every $2 \mathrm{~h}$ after quenching the Fenton reaction. The relative ion count for each product was calculated according to accurate mass and elution time, normalized to an internal control ([Glu1]-fibrinopeptide B doubly charged peptide, $\mathrm{m} / \mathrm{z} 785.8$ ), and values from two experiments were averaged. The $30 \mathrm{~min}$ time point $\left.{ }^{*}\right)$ was acquired once. The inset shows an expanded scale of the key products cysteine sulfinamide cross-link (927.4), and cysteine sulfenic acid (929.4) peptides.

reaction. This type of rearrangement ion $\left(m / z 373, \mathbf{b}_{3}\right)$ was observed in the MS/MS spectra of cysteine sulfonamide, cysteine sulfinamide, and cysteine sulfenamide products that were formed in the oxidation ${ }^{\circ} f^{\circ} \mathrm{PFKCG}{ }^{\circ} \mathrm{by}^{\circ} \mathrm{HOCl}^{\circ}[31]$.
Possible Role for Cysteine Sulfenic Acid Formation in MMP Activation

The activation mechanism of MMPs is believed to involve the disruption of a bond between the thiol

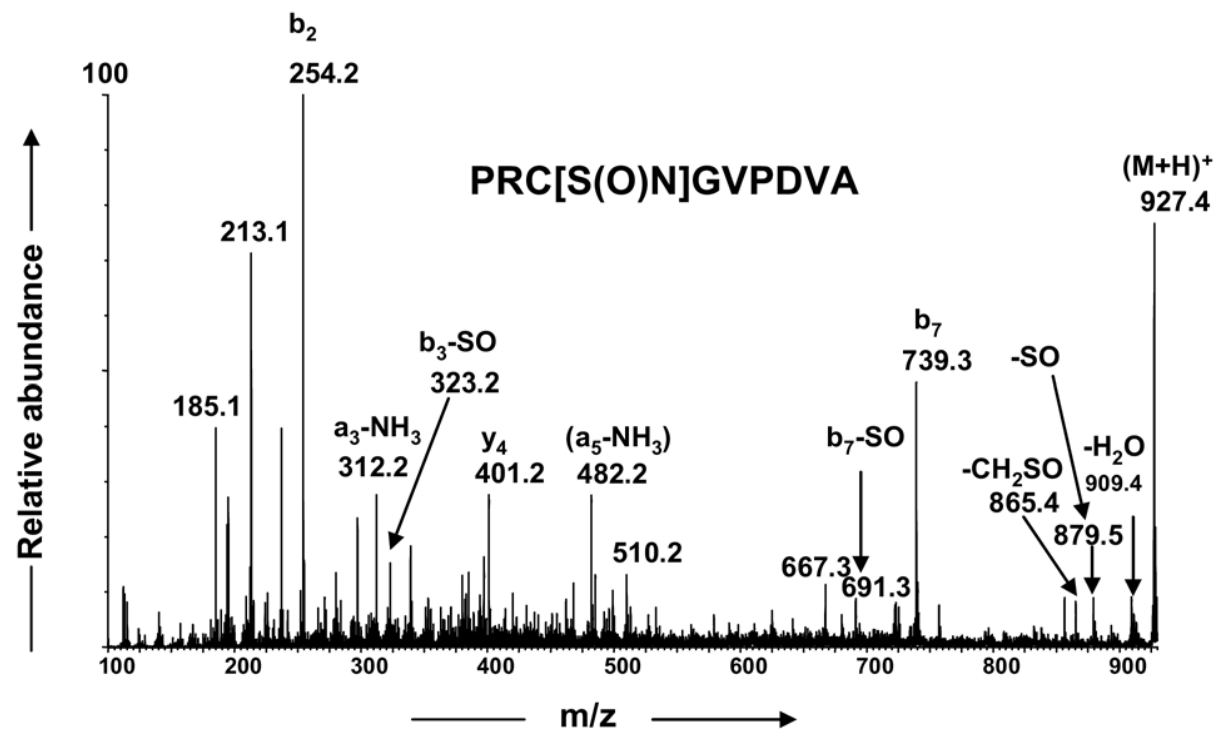

Figure 6. MS/MS spectrum of PRC[S(O)NH]GVPDVA ( $m / z$ 927.4). 



For example, in MMP-7 the oxygenation of thiol by $\mathrm{HOCl}$ disrupts the thiol-Zinc bond and leads to conformational changes that allow autolytic cleavage and access to the enzyme active site. Cysteine sulfenic acid is a central reactive intermediate in many cellular oxidative reaction pathways including the pathway in which cysteine sulfinic acid and cysteine sulfonic acid can $^{\circ}$ be $^{\circ}$ produced $^{\circ}[1-5] .{ }^{\circ}$ The $^{\circ}$ cysteine $^{\circ}$ sulfinamide $^{\circ}$ char- $^{-}$ acterized in this study and as identified previously in the ${ }^{\circ}$ synthetic ${ }^{\circ}$ peptides $^{\circ}$ PFKCG $^{\circ}$ and ${ }^{\circ}$ PFRCG $^{\circ}[31]^{\circ}$ and S100A $8^{\circ}$ protein $^{\circ}[32]^{\circ}$, seems $^{\circ}$ to ${ }^{\circ} e^{\circ} a^{\circ}$ common $^{\circ}$ product ${ }^{\circ}$ in the oxidation reactions of cysteine containing peptides and proteins. Interestingly, in the case of S100A8 protein $^{\circ}[32]^{\circ} \mathrm{a}^{\circ}$ cysteine $^{\circ}$ sulfenic $^{\circ}$ acid $^{\circ}$ intermediate ${ }^{\circ}$ was proposed to be involved in the mechanism of cysteine sulfinamide formation. Since we also identified both cysteine sulfenic acid and cysteine sulfinamide cross link products in the cysteine switch peptide PRCGVPDVA, we believe that PRC(SOH)GVPDVA is a key intermediate in the oxidation reactions of MMP-7 that could further react with reactive oxygen species to form cysteine sulfinic acid and $^{\circ}$ cysteine $^{\circ}$ sulfonic $^{\circ}$ acid $^{\circ}[33]^{\circ}$ or $^{\circ}$ gives $^{\circ}$ rise $^{\circ}$ to $^{\circ}$ novel oxidation products like cysteine sulfinamide cross-link with ${ }^{\circ}$ the ${ }^{\circ} \operatorname{loss}^{\circ}$ of $^{\circ} a^{\circ}$ hydrogen ${ }^{\circ}$ molecule $[32$ ].

\section{Conclusions}

We used an oxidation reaction by hydroxyl radicals generated in the Fenton reaction to generate for the first time a stable cysteine sulfenic acid, [PRC(SOH)GVPDVA], in a synthetic cysteine switch peptide of the matrix metalloproteinase MMP-7. We used tandem mass spectrometry to characterize the structure of the cysteine sulfenic acid as well as an intramolecular cysteine sulfinamide crosslink product, PRC[S(O)N]GVPDVA, in solution. Our results suggest that cysteine sulfenic acid may be involved in regulating the activation of MMPs that contain the cysteine switch sequence.

\section{Acknowledgments}

The authors gratefully acknowledge support from NIH grants S10 RR017990 and 2P30CA016087.

\section{References}

1. Poole, L. B.; Karplus, P. A.; Claiborne, A. Protein Sulfenic Acids in Redox Signaling. Annu. Rev. Pharmacol. Toxicol. 2004, 44, 325-347.

2. Philip, E. Protein Thiol Oxidation in Health and Disease: Techniques for Measuring Disulfides and Related Modifications in Complex Protein Mixtures. Free Rad. Biol. Med. 2006, 40, 1889-1899.

3. Salmeen, A.; Andersen, J. N.; Myers, M. P.; Meng, T.-C.; Hinks, J. A.; Tonks, N. K.; Barford, D. Redox Regulation of Protein Tyrosine Phosphatase 1B Involves a Sulphenyl-Amide Intermediate. Nature 2003, 423, $769-773$.

4. Claiborne, A.; Mallett, T. C.; Yeh, J. I.; Luba, J.; Parsonage, D. Structural, Redox, and Mechanistic Parameters for Cysteine-Sulfenic Acid Function in Catalysis and Regulation. Adv. Protein Chem. 2001, 58, 215-276.

5. Paget, M. S. B.; Buttner, M. J. Thiol-Based Regulatory Switches. Annu. Rev. Genet. 2003, 37, 91-121.

6. Saurin, A. T.; Neubert, H.; Brennan, J. P.; Eaton, P. Widespread Sulfenic Acid Formation in Tissues in Response to Hydrogen Peroxide. Proc. Natl. Acad. Sci. U.S.A. 2004, 101, 17982-17987.
7. Bryk, R.; Griffin, P.; Nathan, C. Peroxynitrite Reductase Activity of Bacterial Peroxiredoxins. Nature 2000, 407, 211-215.

8. Raftery, M. J.; Yang, Z.; Valenzuela, S. M.; Geczy, C. L. Novel Intra- and Intermolecular Sulfinamide Bonds in S100A8 Produced by Hypochlorite Oxidation. J. Biol. Chem. 2001, 276, 33393-401.

9. Kim, J. R.; Yoon, H. W.; Kwon, K. S.; Lee, S. R.; Rhee, S. G. Identification of Proteins Containing Cysteine Residues that are Sensitive to Oxidation by Hydrogen Peroxide at Neutral pH. Anal. Biochem. 2000, 283, 214-221.

10. Allison, W. S. Formation and Reactions of Sulfenic Acids in Proteins. Acc. Chem. Res. 1976, 9, 293-299.

11. Yeh, J. I.; Claiborne, A.; Hol, W. G. J. Structure of the Native CysteineSulfenic Acid Redox Center of Enterococcal NADH Peroxidase Refined at $2.8 \AA$ Resolution. Biochemistry 1996, 35, 9951-9957.

12. Crane, E. J., III; Vervoort, J.; Claiborne, A. ${ }^{13} \mathrm{C}$ NMR Analysis of the Cysteine-Sulfenic Acid Redox Center of Enterococcal NADH Peroxidase. Biochemistry 1997, 36, 8611-8618.

13. van Montfort, R. L. M.; Congreve, M.; Tisi, D.; Carr, R.; Jhoti, H. Oxidation State of the Active-Site Cysteine in Protein Tyrosine Phosphatase 1B. Nature 2003, 423, 773-777.

14. Willett, W. S.; Copley, S. D. Identification and Localization of a Stable Sulfenic Acid in Peroxide-Treated Tetrachlorohydroquinone Dehalogenase Using Electrospray Mass Spectrometry. Chem. Biol. 1996, 3, 851857.

15. Poole, L. B.; Zeng, B.; Knaggs, S. A.; Yakubu, M.; King, S. B. Synthesis of Chemical Probes to Map Sulfenic Acid Modifications on Proteins Bioconj. Chem. 2005, 16, 1624-1628.

16. Ellis, H. R.; Poole, L. B. Novel Application of 7-chloro-4-Nitrobenzo-2Oxa-1,3-Diazole to Identify Cysteine Sulfenic Acid in the AhpC Component of Alkyl Hydroperoxide Reductase. Biochemistry 1997, 36, 1501315018.

17. Fuangthong, M.; Helmann, J. D. The OhrR Repressor Senses Organic Hydroperoxides by Reversible Formation of a Cysteine-Sulfenic Acid Derivative. Proc. Nat. Acad. Sci. U.S.A. 2002, 99, 6690-6695.

18. Sillanpaa, S. M.; Anttila, M. A.; Voutilainen, K. A.; Ropponen. K. M.; Sironen, R. K.; Saarikoski. S. V.; Kosma, V. M. Prognostic Significance of Matrix Metalloproteinase-7 in Epithelial Ovarian Cancer and Its Relation to $\beta$-Catenin Expression. Int. J. Cancer 2006, 119, 1792-1799.

19. Woessner, J. F.; Nagase, H. Matrix Metalloproteinases and TIMPs; Oxford University Press: New York, NY, 2000, pp. 1-240.

20. Marchenko, G. N.; Ratnikov, B. I.; Rozanov, D. V.; Godzik, A.; Deryugina, E. I.; Strongin, A. Y. Characterization of Matrix Metalloproteinase26, A Novel Metalloproteinase Widely Expressed in Cancer Cells of Epithelial Origin. Biochem. J. 2001, 356, 705-718.

21. Wielockx, B.; Libert C.; Wilson, C. Matrilysin (Matrix Metalloproteinase-7: A New Promising Drug Target in Cancer and Inflammation. Cytokine Growth Factor Rev. 2004, 15, 111-115.

22. Van Wart, H. E.; Birkedal-Hansen, H. The Cysteine Switch: A Principle of Regulation of Metalloproteinase Activity with Potential Applicability to the Entire Matrix Metalloproteinase Gene Family. Proc. Natl. Acad. Sci. U.S.A. 1990, 87, 5578-5582

23. Siwik, D. A.; Pagano, P. J.; Colucci, W. S. Oxidative Stress Regulates Collagen Synthesis and Matrix Metalloproteinase Activity in Cardiac Fibroblasts. Am. J. Physiol. Cell. Physiol. 2001, 280, C53-C60.

24. Fu, X.; Kassim, S. Y.; Parks, W. C.; Heinecke, J. W. Hypochlorous Acid Oxygenates the Cysteine Switch Domain of Pro-Matrilysin (MMP-7): A Mechanism for Matrix Metalloproteinase Activation and Atherosclerotic Plaque Rupture by Myeloperoxidase. J. Biol. Chem. 2001, 276, $41279-41287$.

25. Dalle-Donne, I.; Scaloni, A.; Giustarini, D.; Cavarra, E.; Tell, G.; Lungarella, G.; Colombo, R.; Rossi, R.; Milzani, A. Proteins as Biomarkers of Oxidative/Nitrosative Stress in Diseases: The Contribution of Redox Proteomics. Mass Spectrom. Rev. 2005, 24, 55-99.

26. Wang, Y.; Vivekananda, S.; Men, L.; Zhang, Q. Fragmentation of Protonated Ions of Peptides Containing Cysteine, Cysteine Sulfinic Acid, and Cysteine Sulfonic Acid. J. Am. Soc. Mass Spectrom. 2004, 15, 697-702.

27. Men, L.; Wang Y. Further Studies on the Fragmentation of Protonated Ions of Peptides Containing Aspartic Acid, Glutamic Acid, Cysteine Sulfinic Acid, and Cysteine Sulfonic Acid. Rapid Commun. Mass Spectrom 2005, 19, 23-30.

28. Tsaprailis, G.; Nair, H.; Somogyi, A.; Wysocki, V. H.; Zhong, W.; Futrell, J. H.; Summerfield, S. G.; Gaskell, S. J. Influence of Secondary Structure on the Fragmentation of Protonated Peptides. J. Am. Chem. Soc. 1999 121, 5142-5154.

29. Summerfield, S. G.; Cox, K. A.; Gaskell, S. J. The Promotion of d-Type Ions During the Low Energy Collision-Induced Dissociation of Some Cysteic Acid-Containing Peptides. J. Am. Soc. Mass Spectrom. 1997, 8, 25-31.

30. Xu, G.; Chance, M. R. Radiolytic Modification and Reactivity of Amino Acid Residues Serving as Structural Probes for Protein Footprinting Anal. Chem. 2005, 77, 4549-4555.

31. Fu, X.; Mueller, D. M.; Heinecke, J. W. Generation of Intramolecular and Intermolecular Sulfenamides, Sulfinamides, and Sulfonamides by $\mathrm{Hy}$ pochlorous Acid: A Potential Pathway for Oxidative Cross-Linking of Low-Density Lipoprotein by Myeloperoxidase. Biochemistry 2002, 41, 1293-1301.

32. Raftery, M. J.; Zheng, Y.; Valenzuela, S. M.; Geczy, C. L. Novel Intraand Intermolecular Sulfinamide Bonds in S100A8 Produced by Hypochlorite Oxidation. J. Biol. Chem. 2001, 276, 33393-33401.

33. Hamann, M.; Zhang, T.; Hendrich, S.; Thomas, J. A. Quantitation of Protein Sulfinic and Sulfonic Acid, Irreversibly Oxidized Protein Cysteine Sites in Cellular Proteins. Methods Enzymol. 2002, 348, 146-156. 